\title{
歩道橋における振動感覚の数量化と設計への応用 \\ NUMERICAL EVALUATIONS OF PSYCHOLOGICAL EFFECTS \\ OF FOOT-BRIDGE-VIBRATIONS AND APPLICATIONS \\ TO DESIGNS OF FOOT-BRIDGES
}

\author{
西 脇 威 夫* \\ By Takeo NISHIWAKI
}

\section{1. まえがき}

公共構造物を設計する場合に，それの設計の基準とす べき項目として村上 ${ }^{11} は ，(1)$ 合目的性，（2）安全性, （3）経済性，(4) 施工性，(5) 環境との調和を挙げ，そ の中で 合目的性が極めて重要な 意味を持つと述へてい る. また公共構造物は無目的的に建設されることはな く，それは人間の物質的な生活水準を改良するため，あ るいは改良しょうとするプロジェクトの一環として建設 されるのであるから，設計者はその目的が最も効率よく 達成されるように構造物を設計すべきである．また近年 品質管理という概念が構造物の設計ならびに特に施工の 過程に導入されてきつつあるが，それを実施する目標は 構造物の合目的性の追求にほかならないであろう.

従来設計作業において定量的に取扱われるものは，主 として強度に基ゔく安全性であった．構造物が使用に耐 えるということは, 構造物が構造物として最も基本的な 機能を果たしているにすぎないのであって，そのことに よって，それがよい構造物あるいは総合的に能率のよい 構造物であると見なすことはできないであろう．総合的 に構造物の経済性を広い意味で把握しょうとするとき, 合目的性が何かの形で定義づけられ，さらに従来の設計 作業の進め方に立脚すると，それを数量化しておくこと が設計作業を進める上に好都合である.

現存する構造物の大部分は, 数量的には強度を基礎と する安全性の確認のみで設計・架設されてきているが, それらが，おびただしく合目的性から逸脱しているとは 考えられない。これは, 構造力学, 材料ならびに接合法 などが相互に関連し, 強度的にそれの安全性が保証され ることで合目的性がある程度みたされ, 安全性の数量的 評価の陰に合目的性の数量的評価が隠されてしまったた めであろう．そのために合目的性の検討が重視されてい

\footnotetext{
* 正会員 工博 武蔵工業大学教授 工学部土木工学科
}

なかったのではなかろらか. また品質管理という概念が 合目的性の追求のため重要視され, いくたの手法が開発 されつつあるが，いかにすぐれた手法であっても管理の 目標すなわち合目的性が明確化されていない限り管理は 困難である. 構造物に対して望まれるべき要求の数量化 すなわち合目的性の数量化がこの面でも重要な問題とな ってくるのではあるまいか.

高層建築の風に起因する振動による不快感への着目 ${ }^{6)}$ は, 構造物の合目的性の数量化への一つの試みであっ た. 合目的性をどのように定義し, どのように数量的に 評価して設計にそれをしん酌すべきかについては, 不明 な点が極めて多く, その必要性を認めながらも, それへ の実際面でのアプローチの実例は少ない.

歩道橋はその構造も割合簡単であり, かつ架設目的も 他の橋梁と比較すると具体的に把握し易い.すなわち， 歩道橋は危険な車道あるいは歩行に危険または困難な場 所の歩行を歩行者に要求せず, 車道の交通流を停止させ ることなく歩行者に歩行の場を提供し, しかも歩行者が 欲する時刻に安全な歩行の場所を提供しょうとする構造 物である. 横断歩道橋では, 地表を車に譲って歩行者に ある高さまでの昇降を強いるのであるから, 安全である こと以外にその不便さを少しでも軽減する配慮が当然必 要である. 歩道橋上を歩行するとき, 歩道橋の持つ何ら かの原因で歩道橋上の歩行が地上の歩行よりおびただし く不快であったり, 困難となることは, 歩道橋の目的を 上記のように認識する限り, 架橋の目的が十分果たされ ている歩道橋とは認め難いものと考えなければならない と思われる.また横断歩道橋に限らず，在来橋に並列架 設される歩道橋においても, それの快適な歩行性は, 当 然要求されるべきものであって, 計画さらに設計におい て，ただ単純に歩行の空間のみの提供を意図することは 慎まなければならないであろう.

このような観点から,筆者は歩道橋の合目的性に関し， 歩行時に歩行者などが原因となる橋の振動が, 歩行者に 
与える心理的な量一情緒量一を評価することで合目的性 の充足の度合を評価することとした．このような試みに まず必要なことは, 振動感覚の数量化であろら.そして 数量化された振動感覚と情緒量の関係, そして設計にあ たって設計者が制御できる設計変数とそれらの関係を求 めることによって，いわゆる設計作業の中に合目的性の 数量的評価を導入することができるであろう.

\section{2. 振動感覚に関係した最近の研究}

振動感覚に関係した研究として, 古くは 1930 年頃よ り乗心地などの研究, 機械振動の人体への影響などに注 目して, 振動感覚の数量化をはかったものがあり, それ らは，R.J. Steffens' ${ }^{14)}$ あるいは K.M. Solomon ${ }^{15)} ら$ によってまとめられている。

振動感覚を比例尺度上に数量化しようとした試みは小 堀・梶川 ${ }^{2}$ のものと三輪 ${ }^{3)}$ ものがある. 前者は橋上を 歩行する歩行者の心理応答を対象としており, 後者は,

各種の姿勢についての数量化を実施している.これらに ついてはさらに 3. において検討を加える.

数量化された心理的な応答を橋の設計に導入しようと した研究は, 筆者の知る限りでは小堀 ${ }^{4}$ の歩道橋の腹板

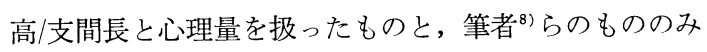
である.

橋梁の振動の歩行者に与える心理的な影響に論及した ものとしては, 松本 ${ }^{17)}$, 牛尾 ${ }^{18)}$, 片山 ${ }^{19)}$, 星谷 ${ }^{20)}$, 小堀 ${ }^{21)}$ の研究がある.

欧米において, 橋の振動が歩行者に及ぼす心理的効果 のことにふれたものは, 筆者の知る限りでは Scatazzini, P. ${ }^{5)}$ のみである. 彼はスイスに支間長約 $46 \mathrm{~m}$ のP C桁 を主構造とする歩道橋が架設されたとき, それが歩道橋 であるので, 振動特性が重要な意味を持つとしてその振 動を測定した. 振動数と振幅の関係は $K$ 值で整理され ている. 集団で歩調を合わせて歩行する場合が, $K$ 值で 30 以上となるが, 単独で歩行する場合の方が多人数で歩 調を合わせず歩行する場合よりやや大きく，前者は 10 をわずかに超えるが, 後者の場合 10 を超えなかったこ とが報告されている．しかしそれらの測定結果に基づい ての設計に対するアプローチには言及していない.

Peter W. Chen らは, 実験室内にての振動に対する 心理的応答に関する測定結果を報告している ${ }^{9)}$. 彼らの 実験はのべ 112 人の被験者に対する $0.067 \sim 0.2 \mathrm{~Hz}$ と いらかなり周期の大きい領域での実験であり, 近年増加 しつつある高層建築物中の居住性の数量的な評価を目指 したものである.心理的な応答として感じない場合も含 めて, 情緒的な応答を 6 段階に分け, 全く感じない場合 (0) またはわずかに感ずる（1）を恕限度とみなし, 恕限
度に影響する因子を調べた。この実験の対象となった振 動数領域では恕限度は振動数に関係せず, 一定加速度で それを表わしらると見なした．また振動に対する期待感 によって恕限度は下り, 被験者が歩行しているか否かに よっても恕限度は異なり, 恕限度に影響を与えると思わ れた因子 7 個に対して恕限度への影響の度合を検討した が，それらのうち最も効果が大であったものは期待感で あったと述べている.さらに, 因子が組合されることに より恕限度の分布の幅が変り, それは対数正規分布にな ると述べている. 従来諸外国の研究例が $1 \mathrm{~Hz}$ 以上であ ることからはこのように低い振動数領域の研究は注目す べきものである.

John F. Wiss らは, 建物の利用者の歩行によって生 ずるような, 床の鉛直過渡振動の心理応答について加速 度, 最大振幅及び減衰定数を因子として, 測定結果を報 告しいる ${ }^{10)}$. 実在の建物の床の振動を測定した結果を基 として, 被験者に実験室において与えるべき過渡振動 を, 約 0.2 秒で最大振幅になりそれ以後減衰し, 増加過 程のピークは直線で, 減衰過程のピークは指数曲線で結 ばれるような波形を提案した. 実験に採用した振動数の 領域は 2.5 25 Hz であった.この実験の範囲では，振 動数と振幅の積が一定の場合に, 一定の応答を示すこと を述べているが,これは小堀や三輪の研究の結果と一致 する. さらに振幅と振動数の積で定義された量と, 5 段 階に分けた情緒量と減衰の間の関係を調べ, 情緒量を指 数法則に準ずる形で表わすと実験結果と最もよく合うと 述べている.

前記の P.W. Chen はかなり低振動数の 振動を取扱 い, J.F. Wiss はそれより高い振動数領域であり，振動 の持続時間はかなり短い振動に対する研究をしたが恕限 度には大きな相違が双方にないことがわかる.

Fu-Kuei Chang ${ }^{11)}$, Robert J. Hansen ${ }^{12)}$,そして J.W. Reed $^{13)}$ は自然風によって生ずる実在の高層建築物の振 動によって，建築物を利用する人がどのような情緒的反 応を示したかを述べている。

Chang はすでに文献 7) に風によって生ずる振動と情 緒との関係を，建物の周期と風によって生ずる振動の振 幅との関係で示しているが, それが実在の建物の使用者 の反応と一致するか否かを 4 つ建物の使用者について 調べた。 その結果として, 風によって生ずる振動は, そ れのパラメーターが狭い範囲でしか動かないから，従来 の実験結果から外插してもよいと述べ,さらに情緒量の おのおのに対応する加速度領域も示した.

Hansen は, 2 つの建物の使用者に対し, 強い嵐のあ とアンケート調査及び面接を行い心理的反応について詳 細な調査を行った. その結果, 建物の居住者は, 短時間 の振動を, 一つの強風時の不快感と認識するので, 1 年 
間に不快感を感ずる場合の数を設計の対象とすることを 提案した.すなわち 1 年間に不快感を感ずるほどの強風 の襲来する確率を求め, その確率を基礎として, 不快感 を感ずる人の期待值を百分率で求める式を示した. それ らより，上記の期待值と，再現期間との関係を示し，一 つの提案として, 設計の対象とすべき強風の再現期間を 6 年としてそのとき居住者の $2 \%$ が不快感を感ずるよう な設計基準を示した.

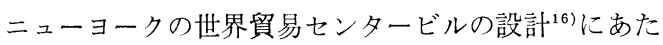
っては，すでに述べた $\mathrm{Chen}^{9)}$ の研究結果に基ゔき，10 $\mathrm{mG}$ の水平加速度をもつ水平振動が発生する回数を 1 年 に 12 回をこえないようにした.

\section{3. 心理尺度と振動感覚}

\section{（1）心理尺度}

人間の行動決定の因子となる刺激と，何らかの意味で その結果と考えられる行動との間に一義的な関数関係を 作ることは一般的には不可能なことであろう. しかし当 面する問題では刺激としてはいくつかのパラメーターか ら成り立つ振動を考え, 行動としては, それをその一側 面から把握する感情またはその強度としての情緒とし て，それらの数量化を試み，それを設計一数量的に反映 させるのが本論の目的である.

振動は, 人間への刺激として, 振幅, 振動速度, 振動

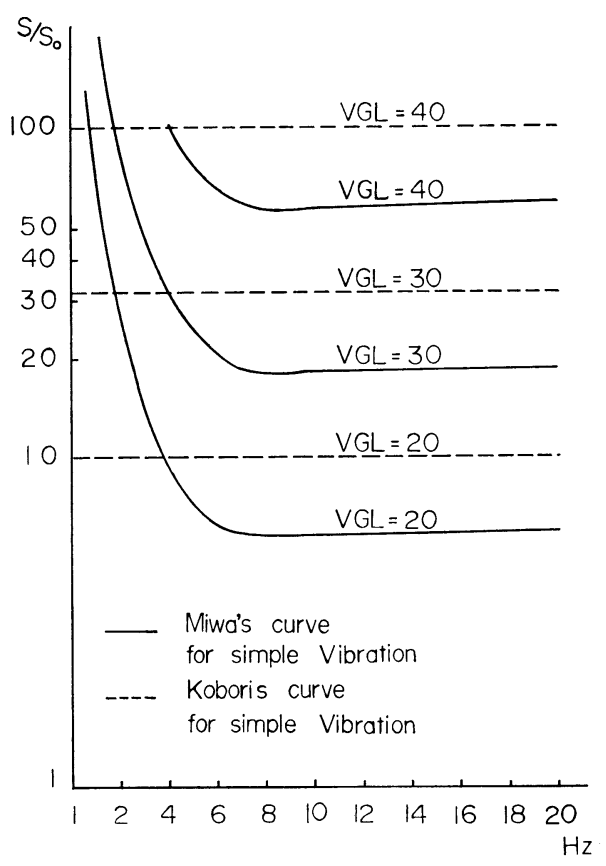

Fig. 1 Equal sensation curves by Miwa and Kobori
加速度, 振動加速度の変化率そして 振動数などを持つ が，それが人閒に加えられたとき，人間には刺激である 振動により, 大小関係のある意識内容がひき起こされ る.ある振動が人間に加えられたときその人間の内面に ひき起こされる意識内容の大小を比例尺度上に求めたも のを振動感覚の心理尺度と称える. 心理尺度が構成され れば, 振動は物理的には前述のように多くのパラメータ 一を持つが，それらが合成された一つの刺激として人間 に作用していると見なすことができ，そのように一次元 の尺度上に数量化された刺激に対応する情緒の強さをさ らに他の一つの尺度上に構成することにより刺激と行動 間の関数関係を見出し得るものと見なすこととする. 本 論では, 情緒は序数尺度上に構成した.

問題としている橋の振動に起因する歩行者の振動感覚 の数量化に用いる現時点で構成されている心理 尺度に は, 小堀 ${ }^{2}$ の尺度と三輪3)の尺度があり本論ではその両 者によって振動感覚の数量化を行った. そこで, 以下数 量化を行って振動感覚を評価するうえに重要と思われる 二, 三の点について比較検討する.

\section{（2）等感度曲線と振動レベル}

振動によって生ずる人間の意識内容は，すでに述べた 振動の各種のパラメーターの組合せによって, あるレベ ルに達する.これらは，小堀や三輪が実施したように， 被験者に各種の組合せから成るいくつかの振動を与え， 被験者の意識が等しくなるものを被験者に選択させるこ

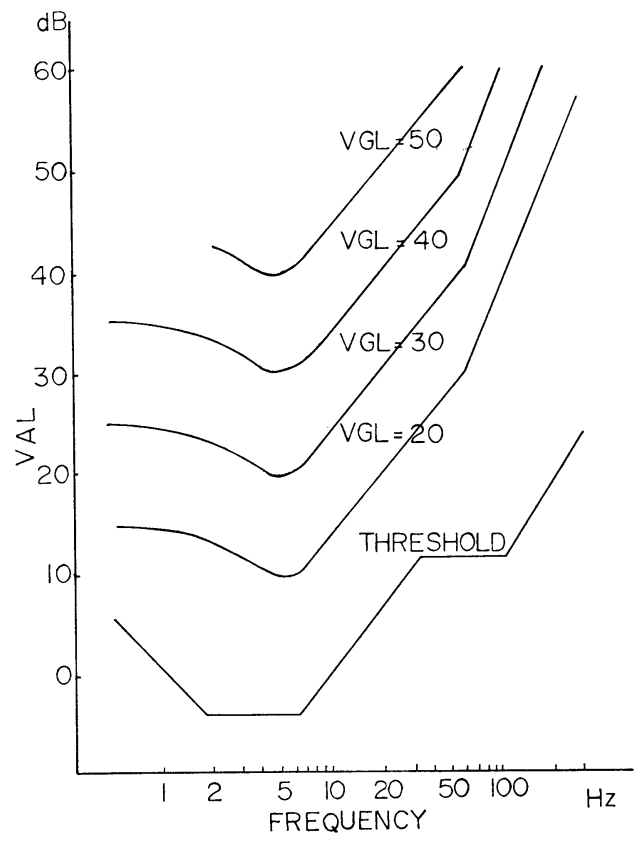

Fig. 2 Equal sensation curves represented by acceleration levels by Miwa 
となどにより得られる.

このようにしていわゆる等感度曲線が得られるが，両 者の求めた等感度曲線の最も大きな相違は, 被験者に与 える振動の振動数が $20 \mathrm{~Hz}$ 程度までのとき, 小堀は, 振動感覚は, 振動速度によってのみそれが支配されるも のとした．すなわちその範囲ではある振動速度の振動は どのような振動数の振動であっても, それを同一のレべ ルとして被験者は受取るというのに対し，三輪は，6 8 $\mathrm{Hz}$ から $20 \mathrm{~Hz}$ 位までは，小堀とほぼ同じと見なす，が それ以下では必ずしも一定振動速度が一定振動レベルに 対応するとはしていない点にある.橋の振動がかなり低 い振動数領域で発生していることから，この相違は数量 化に一つの問題を与えている. 両者の関係を示すものが Fig. 1 である. 三輪は Fig. 2 亿示すように加速度レ ベルで等感度曲線を与えているので, それを速度レベル に変換して Fig. 1 亿三輪の曲線として示した.

振動レベル $(V G L)$ はそれぞれ次式で与えられてい る.

$$
\left.\begin{array}{cc}
\text { 三輪の振動レベル } & V G L=20 \log _{10}\left(\frac{a}{a_{0}}\right) \\
& a_{0}=1 \mathrm{~cm} / \mathrm{sec}^{2} \\
\text { 小堀の振動レベル } & V G L=20 \log _{10}\left(\frac{S}{S_{0}}\right) \\
& S_{0}=1.4 \times 10^{-2} \mathrm{~cm} / \mathrm{sec}
\end{array}\right\}
$$

なお三輪はすでに述べたように振動数によって振動感覚 が異なるので $V G L$ としては, $20 \mathrm{~Hz}$ のときの感覚を基 礎として，等感度曲線を構成した。

\section{（3）振動の大きさ}

上述の振動レベルは，それぞれ与えられた振動を同じ レベルに感ずる加速度レベルまたは速度レベルを示すの であって, それらはともに比例尺度上に構成されている ものではない. 感覚を数量化し, 設計計算に数量として 用いるためにはそれらに四則演算の可能性を与えなけれ ばならない，すなわち振動レベルを比例尺度上にあらた めて構成することが必要である. この比例尺度上の数值 の単位として, 両者とも $V G$ を用いている.

振動の大きさ $V G$ は，それぞれ次式で与えられてい る.

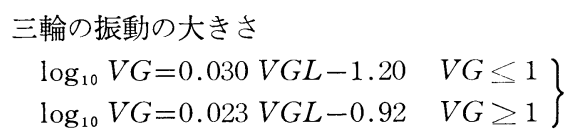

小堀の振動の大きさ

$$
\left.\begin{array}{ll}
\log _{10} V G=0.05 V G L-2.0 & V G L \leq 40 \\
\log _{10} V G=0.03 V G L-1.20 & V G L>40
\end{array}\right\}
$$

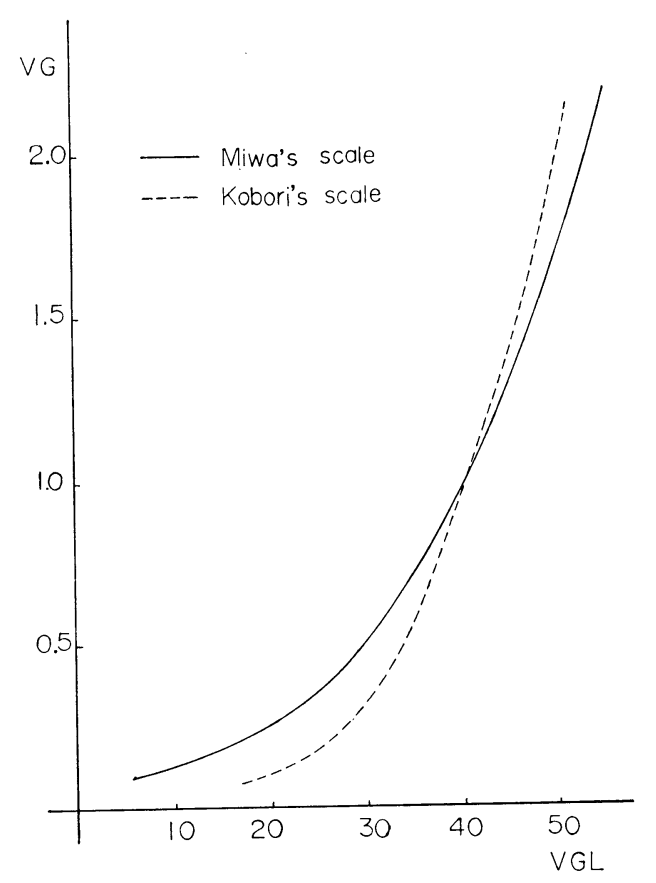

Fig. 3 Relations between Miwa's scale and Kobori's scale

これらの関係を示すものが Fig. 3 である. 双方, $V G L$ が 40 の振動の大きさを 1 としているが, Fig. 1 に示したように, ほぼ $4 \mathrm{~Hz}$ の振動の振動レベルが両者 で一致している。 また三輪は式 $(3.2 \cdot a)$ の周波数依存 性を実験的に確認した結果大きな依存性は認められない と述べている゙'.

振動速度 $S$ の正弦振動を, 両尺度で評価するときに両 尺度によって生ずる差を示したものが Fig. 4 である.

また両尺度で与えられる $V G$ の関係を示したものが

Fig. 5 である.

\section{（4）複合振動の振動の大きさ}

（3）に述べたことは, 人間に加えられる振動が単一の 振動数成分のみを持つ単純正弦振動の場合に対するもの である.われわれが実際に橋あるいは建物などから感ず る振動は, 通常の場合, 単純な正弦振動の合成である複 合正弦振動またはそのように見なしらる振動であって， このような振動による感覚が実際上は重要である.

前述のように, 三輪の尺度と小堀の尺度は (1)〜 (3) の範囲では数值のとり方などに若干の差異はあったが, 尺度を構成する思想に大きな相違はなかった。しかし複 合振動の評価については, 両尺度はその見解をやや異に している.

三輪は 2 4 個の振動数成分から成り立つ複合正弦振 動の各成分の振動レベルと, $20 \mathrm{~Hz}$ の単紝正弦振動のレ ベルが等しくなるものを実験的に求めて，それを式(3.2 


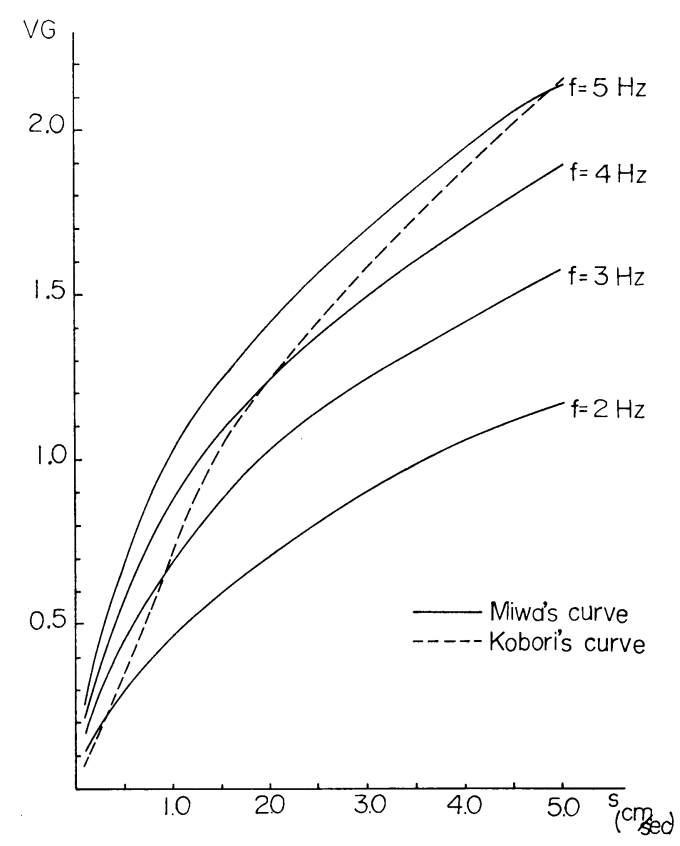

Fig. 4 Vibration greatness evaluated by Miwa's scale and Kobori's scale

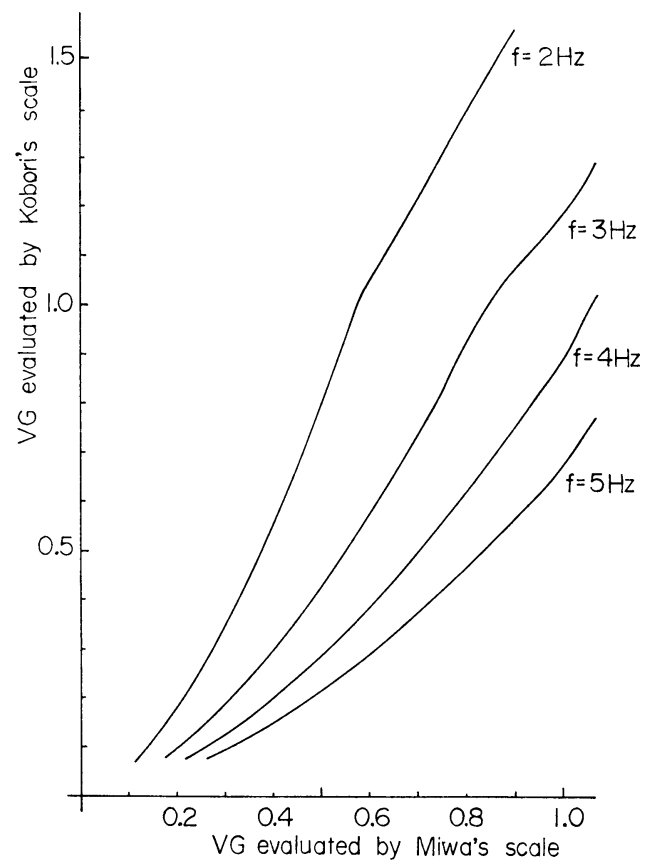

Fig. 5 Theoretical Relations between Miwa's scale and Kobori's scale

•a）で振動の大きさに換算した. さらに各成分間に，

S.S. Stevens の荷重加算法が成立するとしてその係数 を実験的に求めた。その結果次式を得ている3

$$
V G_{T}=V G_{M}+0.3\left(\sum V G_{i}-V G_{M}\right) \cdots(3.3 \cdot a)
$$

一方小堀は， 2 つの正弦振動を成分とする複合正弦振
動を被験者に与え，2つの成分のうち基本となる振動成 分の振動数を持つ単純正弦振動と，与えた複合正弦振動 の振動レベルが等しくなる単純正弦振動の振動数と振幅 をまず求めた。それより等価された単純正弦振動の振動 速度と, 被験者に与えた複合正弦振動の成分の速度の二 乗和の平方根を比較した結果より成分の二乗和の平方根 によって $S$ を求めてよいとした.

すなわち

$$
S=\left\{\sum \sigma_{v i}{ }^{2}{ }^{1 / 2}\right.
$$

\section{（5） ランダム振動の振動の大きさ}

複合正弦振動と同様にこの場合にも，両者は見解を異 にする. 三輪は等感覚曲線が, 単純正弦振動のものと若 干異なることを述べ, $12 \mathrm{~Hz}$ の単純正弦振動は, 1 オク ターブバンドランダム振動（中心周波数）より約 $7 \mathrm{~dB}$ 強く感ずると述べている. またランダム振動の等感覚曲 線を加速度の実効值のレベルで描くと，3〜15 Hz で， 周波数に関係せず一定であり，さらに等感覚曲線はバン ド幅が $1 / 3$ オクターブになっても変らないと報告してい る. また各成分の振動の大きさと, ランダム振動の大き さの間には, S.S. Stevens の荷重加算法が複合正弦振 動の場合と同様に成立すると報告している. 式 (3.3・a) を $1 / 3$ オクターブバンドで求めた成分を用いて示すと次 式になる.

$$
V G_{T}=V G_{M, 1 / 3}+0.13\left(\sum V G_{i, 1 / 3}-V G_{M,,_{1 / 3}}\right)
$$

小堀は実橋の測定記録をランダム振動として被験者に 与え, それの卓越振動数をもつ正弦振動と等しい振動レ ベルとなる振幅を求めた. その結果, 橋梁の振動に関す る限り，正弦振動によって得られた評価法がそれに適用 できると述べている。

\section{（6）歩道橋の振動による両尺度の比較}

後に示す東京都内にある 23 橋の歩道橋の実測記録に 対して，両者の心理尺度を用いて振動の大きさを求め た. 得られた振動は複雑な波形を示してはいるが，それ らはランダム振動ではなく, 複合正弦振動であると見な して，三輪の尺度による場合，正弦振動の等感覚曲線に よったが，測定值の整理を $1 / 3$ オクターブごとに整理し たので, $V G_{T}$ の算出は式 $(3.3 \cdot \mathrm{c})$ によった. その結果 を Fig. 6 に示す.

卓越振動数をパラメーターとして, 両者を比較する と，両者間に法かなりよ直線関係が得られる．その一 例を Fig. 7 に示寸. 小堀の尺度によって求められる $V G$ を $Y$, 三輪の尺度によって得られるそれらを $X$ と すると

$$
Y=a X-b
$$


Fig. 6 に示されたデータを卓越振動数ごとに分類し て, 直線回帰を行って得られた係数 $a, b$ を Table 1 に 示す.

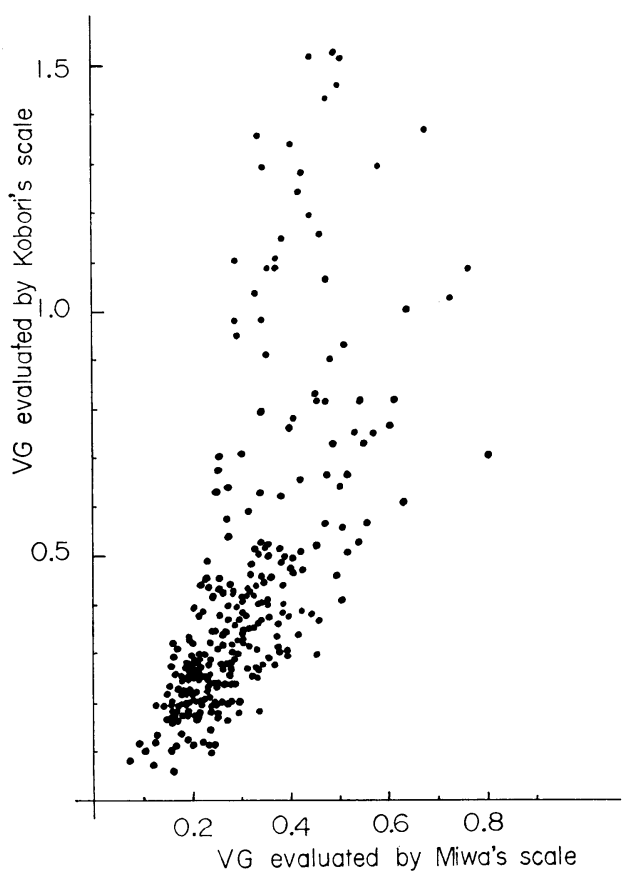

Fig. 6 Measured Relations between Miwa's scale and Kobori's scale

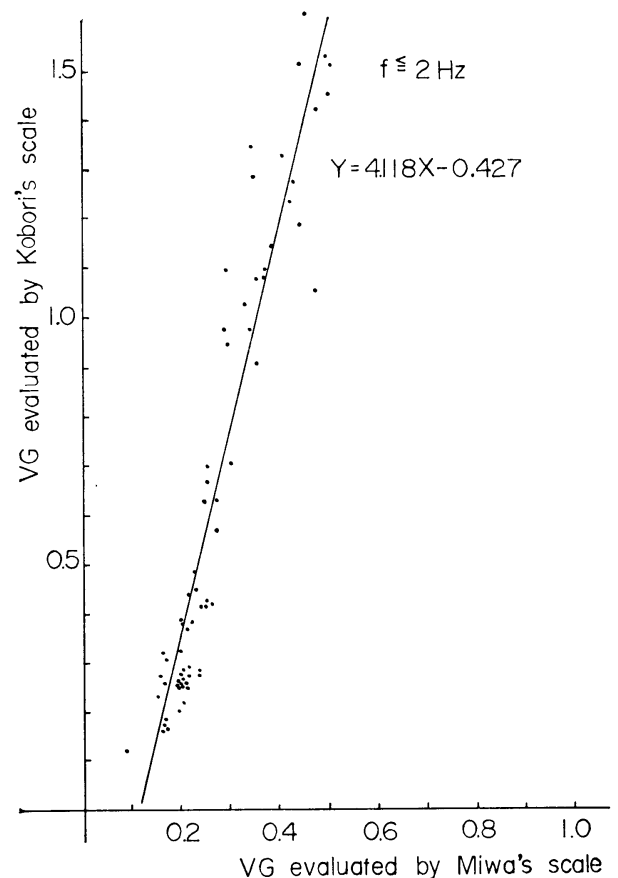

Fig. 7 Relation between Miwa's scale and Kobori's scale
Table 1 式 (3.4) の係数 $a, b$

\begin{tabular}{c|c|c}
\hline 卓越振動数 & $a$ & $b$ \\
\hline $2 \mathrm{~Hz}$ 以下 & 4.118 & 0.427 \\
$2 \sim 3 \mathrm{~Hz}$ & 1.969 & 0.166 \\
$3 \sim 4 \mathrm{~Hz}$ & 1.312 & 0.043 \\
$4 \mathrm{~Hz}$ 以上 & 1.773 & 0.246 \\
\hline
\end{tabular}

卓越振動数が $4 \mathrm{~Hz}$ 以上のカテゴリーに属する振動の 場合は，卓越する振動成分の振幅と他の成分の振幅とに 顕著な差が見出し得ないが，それ以外の場合は卓越する 振動成分の振幅に対し他の成分の振幅はかなり小さくな る傾向を持っている.

\section{（）振動の大きさと情緒}

以上述べた振動の大きさは, 人間に加えられた刺激に 対する人間の感覚（知覚器官によって得られる反応）で ある.そのような感覚として得られた刺激が人間に好ま しいものであれば，それをより多く採入れる方向への運 動が生じ，それを忌避すべきものと認めればそれから遠 ざかろうとする運動が生ずる.この運動にもレベルが存 在し，そのレベルを情緒レベルとする。

本論で採用したレベルは Table 2 に示す 5 段階であ る.

Table 2 情緒レベル

\begin{tabular}{l|l}
\hline 1 & Imperceptible \\
\hline 2 & Barely perceptible \\
\hline 3 & Distinctly perceptible \\
\hline 4 & Strongly perceptible \\
\hline 5 & Severe \\
\hline
\end{tabular}

\section{4. 数量化された歩道橋の振動}

\section{（1）測定とデー夕処理}

測定の対象とした歩道橋は，都内にあってその諸元が 明らかであり，歩行者の比較的多いと見なされたもの, さらに本学よりなるべく近くに存在しているものとし た.さらに構造は単純支持または 2 径間の連続支持とな っていて, 力学モデルと実橋の構造形式がなるべく近く なるものを選んだ. その総計は 23 橋である.

現場における実測は，午前 8 時より午後 5 時まで, 15 分間隔に支間中央の鉛直振動加速度を, アナログデータ レコーダに記録するとともに，その時点の歩行者数を記 録し,さらにその時の歩行者に対し渡り終ったときに面 接して，アンケート調査を行った.

データレコーダに記録されたデータは，研究室におい て AD 変換して紙テープに穿孔し,その紙テープより直 ちに電子計算機により，両尺度による振動の大きさな 
ど, 任意の必要な解析結果が計算機 出力として得られるようにした。

\section{（2）測定結果}

測定したデータを心理尺度を用い て振動の大きさに変換したものの一 部を各橋ごとに三輪の尺度で示すと

Fig. 8 になり,一つの橋において 荷重の状態（歩行状態）によって, 振動の大きさはかなり広い幅に分布 することがわかる.

Fig. 9 に, 15 分ごとに測定した 振動の大きさとその時の歩行者の数 との関係の一例を示した. 歩行者数 には時刻によって明らかに卓越する ところが存在する.この橋は, 小中 高校㧍よび大学が近くにあり, それらの生 徒・学生の下校時に明らかなピークが歩行 者数において生ずる. 一方振動の大きさに は, 歩行者の数ほど顕著なピークが生じな い. 振動の心理的な大きさに関係するもの として, 歩行者の数はそれほど大きな影響 を持たないと思われる.

歩行者に対する面接アンケートは, 約 500 名の歩行者に対して実施された. その 解答は, 心理的な大きさに関係すると思わ れるいくつかの因子に対して分析された が，それら因子の代表的なものとして 1) 性別，2）歩行状態，3）歩行の目的，4）年 令，5）はき物，6）職業などが分析の対象 となった. これらの因子に対する歩行者群 の構成は Fig. 10 のようであった。

\section{（3）歩行者の振動感覚と情緒量}

歩行者または橋上に静止する者が, 歩行 者によってひき起こされる振動によって感 ずる振動感覚の大きさ（三輪の尺度による $V G_{T}$ または小堀の尺度による $\left.V G\right)$ と，

Table 2 に示す情緒量の関係をすべて のデータを用いて累積分布曲線で示すと

Fig. 11 (a) およびFig. 11 (b) のごとく なる. Fig. 11 (a) において情緒量 1 の累 積曲線の $10 \%$ から 100\% までに対応する 振動の大きさは $V G_{T} 0.05$ から $V G_{T} 0.2$ までの $V G_{T}$ の差は 0.15 であるのに対し， 他の情緒量の累積曲線は, その 2 3 倍の 幅にわたっている.これは, 振動を感じな

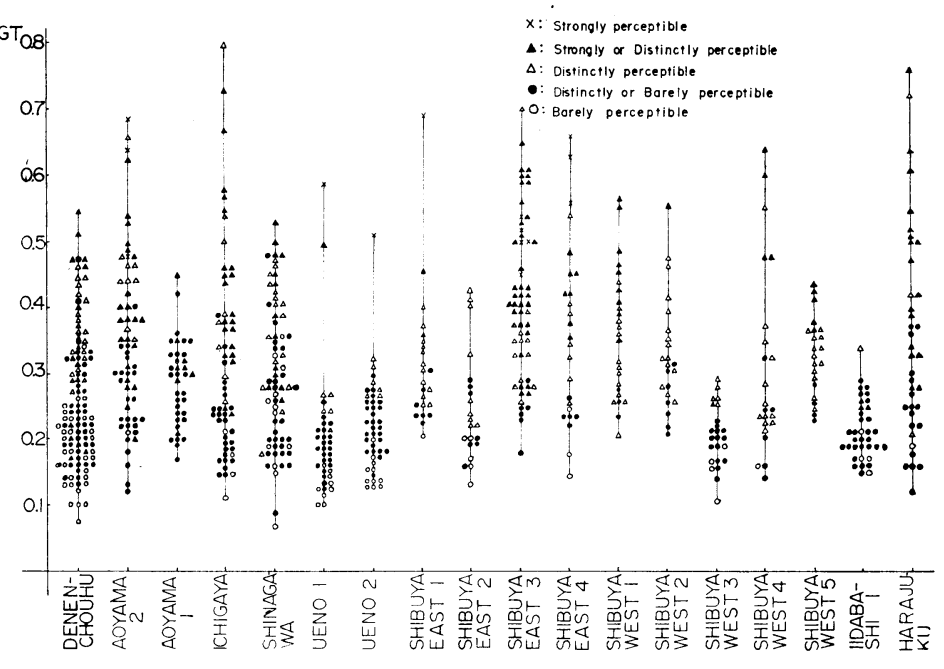

Fig. 8 Measured Vibration Greatness

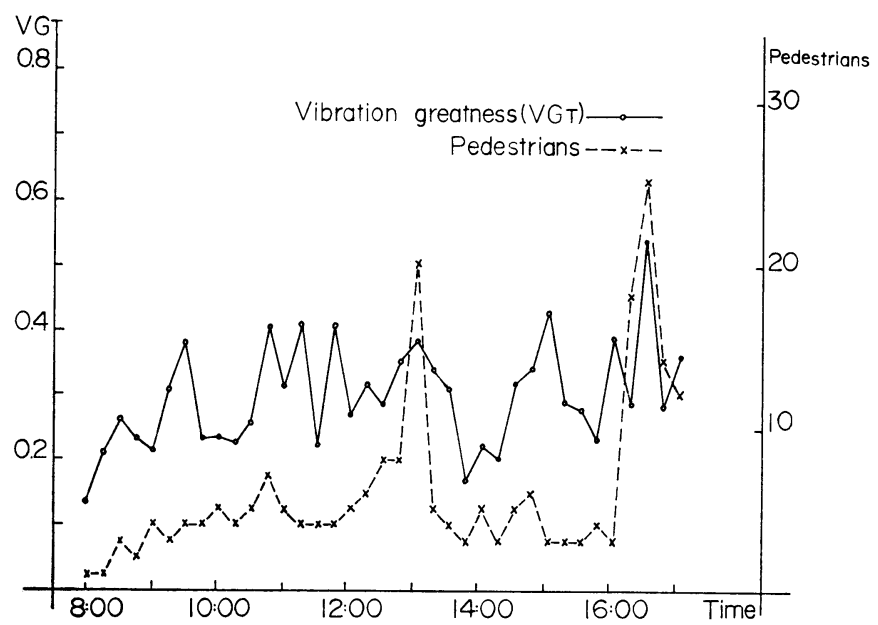

Fig. 9 Vibration greatness and Numbers of Pedestrians
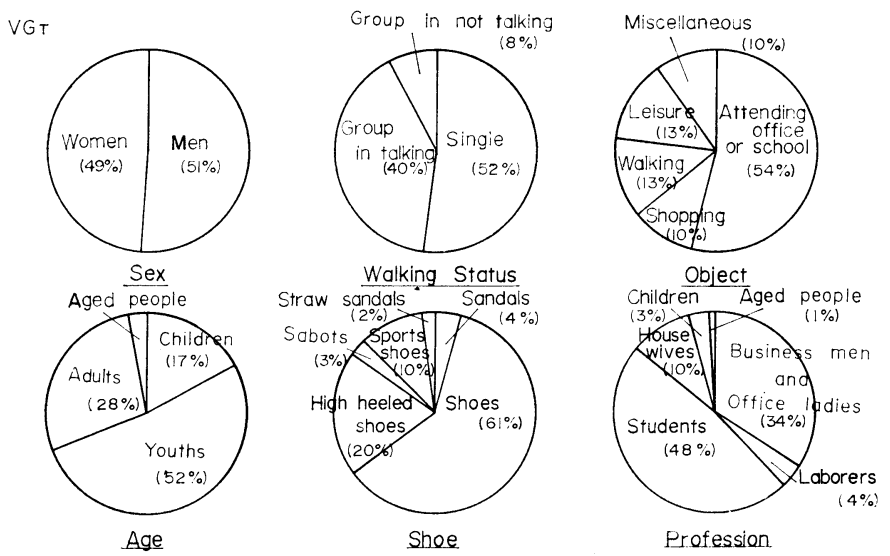

Fig. 10 Constitutions in each of factors 


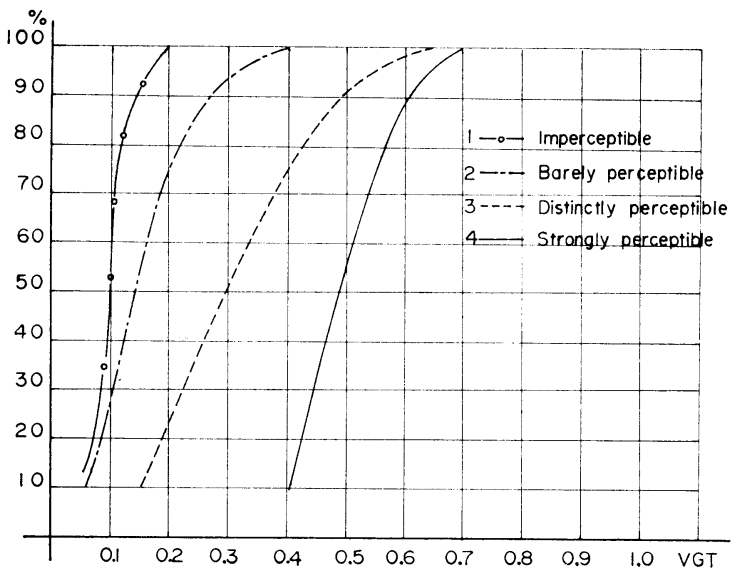

(a) Standing

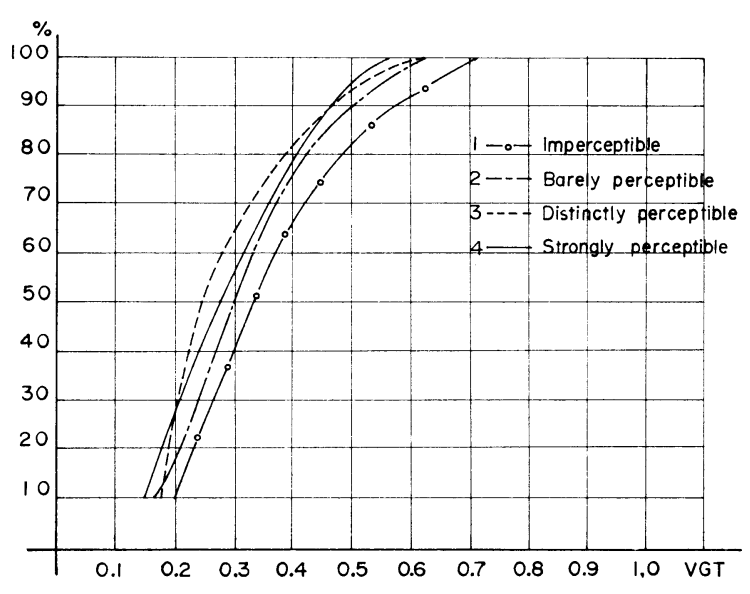

(b) Walking

Fig. 11 Cumulative distribution curves for Emotions of Pedestrians on Foot-bridges

いことに対する大勢の人の意見は一致するが, 振動の感 じ方には個人差があることを示し，振動による情緒量の 数量化の難しさと, さらに，もし将来それを示方書ある いは指針などに導入するとしたならば，技術的な視点か らではない検討が必要であることを示しているものと見 てよいであろう．情緒 1 の $50 \%$ 累積值に対する $V G_{T}$ の值を以て振動の恕限度とするならばそれらは, Table 3 のようになる. これより極めて平均的には, 歩行中に は, 静止状態において振動を感じ始める振動の 3 倍の振 動で, ようやく振動を感ずるといらことがわかる. 静止 中の人が感ずる振動の大きさと情緒の関係は, 同じよう に累積值 50\% に対応する值をとると, Table 4 のよ うに評価できる。

一方歩行中には静止中に比べて振動に対する情緒は鈍 くなり全体として情緒的な認識程度を論ずることは難し い.Fig. 10 に示したような因子ごとに累積值 $50 \%$ に 対する $V G_{T}$ 值で情緒を示すと Table 5 のようにな
Table 3 恕 限 度

\begin{tabular}{cc|c|c}
\hline & & 三輸の尺度 $\left(V G_{T}\right)$ & 小堀の尺度 $(V G)$ \\
\hline 歩 行 中 & 0.35 & 0.36 \\
静 止 中 & 0.10 & 0.16 \\
\hline
\end{tabular}

Table 4 情緒量と振動の大きさ（静止中）

\begin{tabular}{l|c|c|c|c|c}
\hline 情 緒 量 & 1 & 2 & 3 & 4 & 5 \\
\hline 振動の大きさ & 0.1 & 0.15 & 0.3 & 0.5 & - \\
\hline
\end{tabular}

Table 5 振動の大きさ

\begin{tabular}{|c|c|c|c|}
\hline & Emotion & 1 & 2 \\
\hline Fact & & Imperceptible & $\begin{array}{c}\text { Barely } \\
\text { Imperceptible }\end{array}$ \\
\hline & anding & 0.10 & 0.13 \\
\hline & Men & 0.32 & 0.35 \\
\hline & Women & 0.31 & 0.32 \\
\hline & Businessmen & 0.30 & 0.38 \\
\hline & Laborers & 0.37 & 0.40 \\
\hline & Students & 0.32 & 0.34 \\
\hline & Housewives & 0.25 & 0.28 \\
\hline & Children & 0.36 & 0.27 \\
\hline Walking & Single & 0.33 & 0.37 \\
\hline & Talking & 0.39 & 0.31 \\
\hline & $\begin{array}{l}\text { Group Not } \\
\text { talking }\end{array}$ & 0.30 & 0.26 \\
\hline & Business & 0.33 & 0.37 \\
\hline & Shopping & 0.27 & 0.27 \\
\hline & Walking & 0.26 & 0.20 \\
\hline & Miscellaneous & 0.32 & 0.34 \\
\hline
\end{tabular}

る.情緒として 1 および 2 のみ示してあるが, アンケー 卜調查の答えとしては 3 ，または 4 も存在している。し かし，3および 4 と答えた人は，おそらくは，アンケー トを受けてはじめて振動の大きさを意識したもので, 歩 行中振動の大きさに特に関心を持っていなかったのでは ないかと思われるので，それらは集計の対象とはしなか った.

かなり明瞭に情緒の変化が見られる因子としては, 性 別における男性, 歩行状態別における単独, 歩行目的別 における通勤通学, 年代別における青年および壮年, 靴 の種類別においては革靴そして職業別においてホワイト カラー族と学生などである.それらの累積曲線の一例を

Fig. 12 (a) および Eig. 12 (b) に示す.

Table 5 において情緒 1 に対応する振動の大きさの うち, 因子 “主婦”, “買物”および “散歩”と, 因子“木 ワイトカラー”, “労働者”, “学生, 生徒”, “ビジネス”に 属するものとの間に $0.05 \sim 0.1$ の違いがある.このこと は住居地域と考えるべきところと, ビジネス地域とみな しうるところでは, 利用者の振動に対寸る心理的反応に 数量的な違いがあると見なしてよいことを示していると 考えてよいであろう. 振動の感覚を設計因子とすれば, ビジネス地域に架ける歩道橋より, 住居地域に架ける橋 


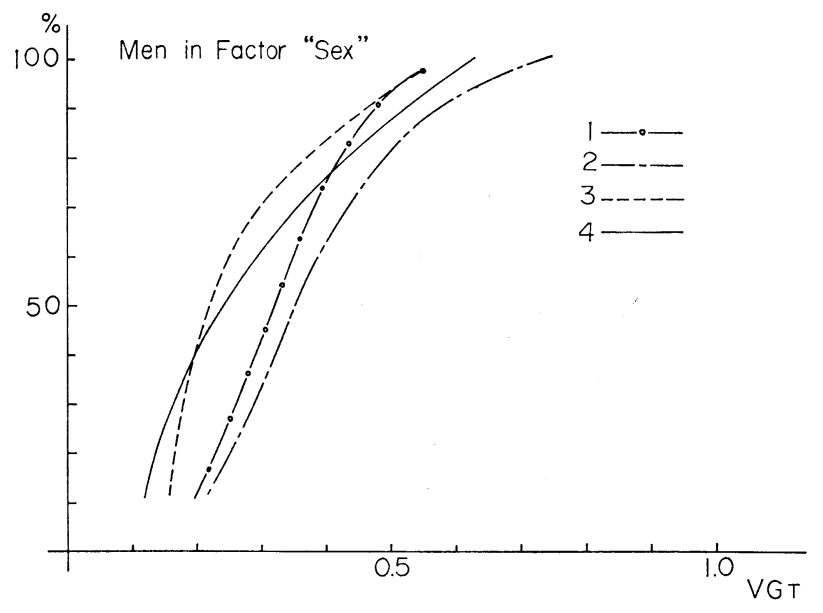

(a)

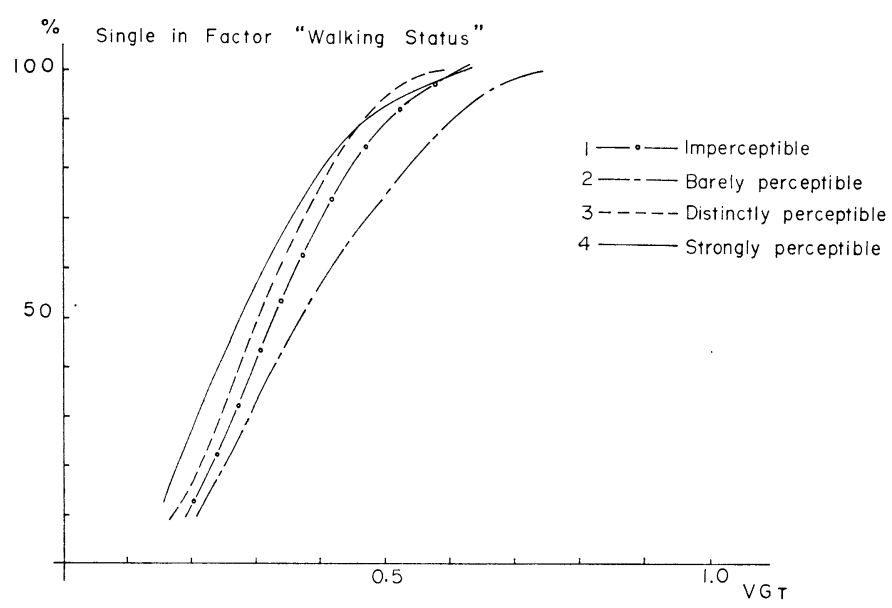

(b)

Fig. 12 Cumulative distribution curves for Emotions of pedestrians on Foot-bridges

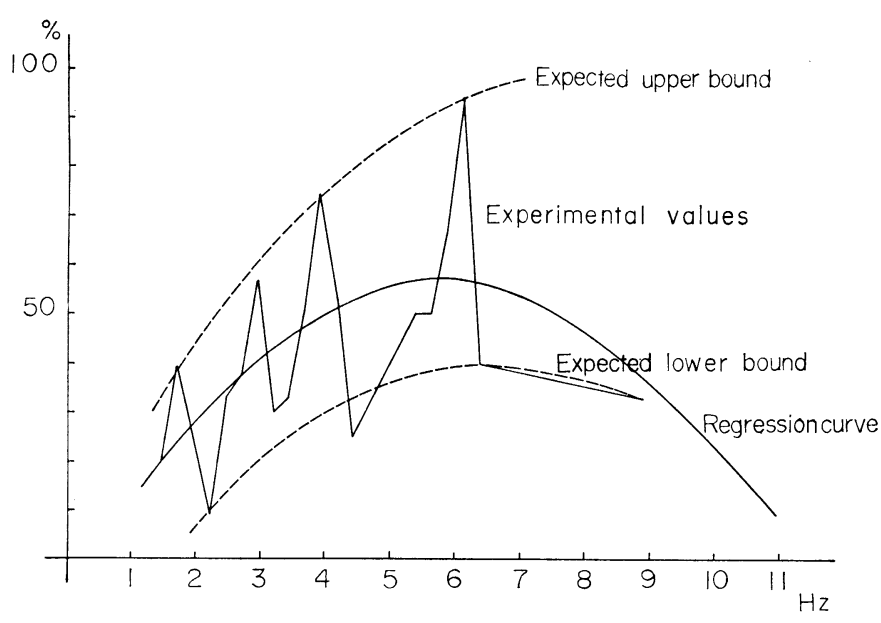

Fig. 13 Probability curve that pedestrians feel such that vibrational greatness is greater than 0.3
に対し篇しい条件をつけても，合目的性 は数量的に同一となることを示唆してい る.

さらに男性と女性を比べると，女性の 方がやや鋭く振動を弁別しており，特に 職業別で分類すると主婦の弁別の度合は 鋭い. 歩行目的で分類すれば，買物とか 散歩の場合が鋭く, 勤務中は感覚が鈍く なっている傾向が見られる.

\section{5. 振動の大きさと歩道橋の構造 特性}

\section{（1）卓越振動数と振動の大きさ}

測定分析した歩道橋の振動記録の振動 数スペクトラムから，それについて次の ような特性があることがわかった.すな わち，(1) $10 \mathrm{~Hz}$ をこえる振動数成分が 含まれることはあまりなく，あっても極 めて小さい。（2）最も大きな值を持つ成 分の振動数が $3 \mathrm{~Hz}$ 以下の場合には, そ れ以外の成分は小さい。(3) 最も大きな 值を持つ成分の振動数が $3 \mathrm{~Hz}$ を越える 場合は，それに続く大きさの成分の大き さが, 最大成分のそれに比べて, たいし て小さくならない.

このようなことから, 振動数スペクト ラムの中で卓越する振動成分の振動数 と, 振動の大きさの関係を調べた. Fig. 13 にその一例を示す. 測定されたデー 夕のうち，振動の大きさが 0.3 を越える 場合の数の割合を縦軸に, 横軸に卓越振 動数をとった. 換言すれば, 振動の大き さが 0.3 を越える確率を実測された卓越 振動数に対して示したことになる. 荷重 である歩行者の歩調は, それの平均値が 1.99 歩/秒 ${ }^{17)}$ であると報じられているが， これから見ると歩行者の歩調による周期 的加振は, 特殊の場合を除けば，それほ ど大きな影響を持っていない. 平均值が 1.99 歩/秒の周期的加振力を持つ荷重が, 確率的に位相差を持ちながら分布して橋 に進入すると見なすと, その分布はポア ソン分布になるといわれており ${ }^{17), 18)}$, 歩 道橋の荷重はいわゆる不規則な変動荷重 であるからであろう。 
また卓越振動数と，計算で得た固有振動数も必ずしも 一致しない.たとえば, $2.3 \mathrm{~Hz}$ の固有振動数を持つ橋 の測定データ 38 個のうち, 卓越振動数が $3.6 \mathrm{~Hz}$ のも の $2,3.9 \mathrm{~Hz}$ のもの $14,4.2 \mathrm{~Hz}$ のもの $19,4.4 \mathrm{~Hz}$ のもの $1,6.8 \mathrm{~Hz}$ のもの $1,8.5 \mathrm{~Hz}$ のもの 1 であり, 半数のデータが $4.2 \mathrm{~Hz}$ の卓越振動数を持った.ほとん どのデータの卓越振動数は固有振動数より大きいが, 中 には固有振動数 $2.2 \mathrm{~Hz}$ の橋の測定結果 36 データのう ち $1.7 \mathrm{~Hz}$ のデータが $12,2.0 \mathrm{~Hz}$ のデータ $23,2.2 \mathrm{~Hz}$ のデータ 1 のごとく, 固有振動数より低めの卓越振動数 を持つ測定結果が得られたものもある.

これらから，橋の固有振動数または，橋を加振する荷 重の持つ周期性が直接, 橋の振動の心理的大きさに関係 してはいないと思われる。

また，同図から，振動の大きさが 0.3 を越える確率に, 下限值と上限值が存在 することが推定できる．たとえば，测定 して得られる卓越振動数が $3 \mathrm{~Hz}$ のとき には，振動の大きさが 0.3 を越える確率 は，25\% 55\% と，本測定からは推定で きる。

上述のようなデータの整理は, 振動の 大きさが 0.3 以外の值に対しても可能で ある.ここで 0.3 としたのは, 情緒とし て4またはそれ以上を考えることを意味 し，歩行中に振動していることをかなり 不快に感ずる状態を取扱ったものであ る.

\section{（2）剛度との関係}

剛度に関係するパラメーターと して $g E I / w l^{4}$ を採り上げる.こ れの平方根に, 支持条件より定ま る係数を乗ずると，その橋の固有 振動数となる. したがって Fig. 13 に示した横軸が，橋に対する 実測振動数であるのに対し，Fig. 14 で取扱うパラメーターは計算 による固有振動数に関係する值 で, 設計するおりに, 設計者の判 断で選ぶことの可能となる数值で ある.パラメーターとして固有振 動数を採ることもできるが, 測定 される橋の境界条件は必ずしも力 学的に厳密な状態とはなっていな い場合もあり得るので，境界条件 の入っていない值とした.
横軸にパラメーター $g E I / w l^{4}$ を採り, 縦軸にある大 きさの振動の発生する確率をとる. Fig. 14 は, 振動の 大きさを $V G_{T}$ で表して 0.3 の場合を示す. 折れ線で示 されるものが実測の結果として得られ，それらから求め た回帰曲線も示してある.この図からわかることは，(1) 単純橋の方が連続橋に比べ，振動の大きさが 0.3 を越え る確率は一般的には大きく，回帰曲線で比べて $10 \%$ 以 上の相違がある。（2）VG が 0.3 を越える確率が $50 \%$ であるような単純支持の歩道橋の $g E I / w l^{4}$ は $6 \sim 400$ で あって，ほとんどすべての単純支持の歩道橋はこの中に 含まれるのに対し，連続支持であると $g E I / w l^{4}$ は $5 \sim 80$ であって，この範囲に含まれない歩道橋も存在する。こ のことは単純支持の歩道橋の場合，すべての橋の歩行者 の半分は不快感に近いものを感じているといえる.(3)

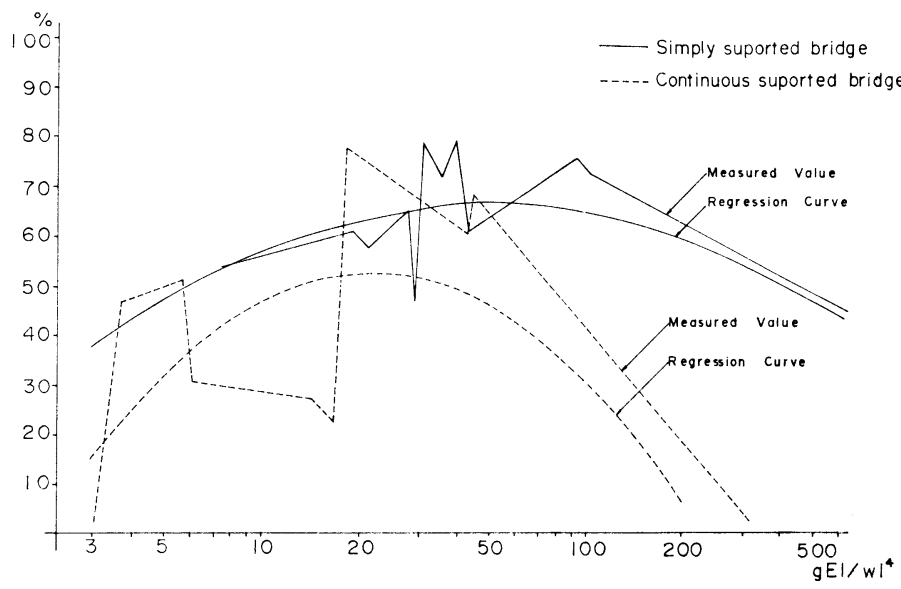

Fig. 14 Probability curve that pedestrians feel such that vibrational greatness is greater than 0.3

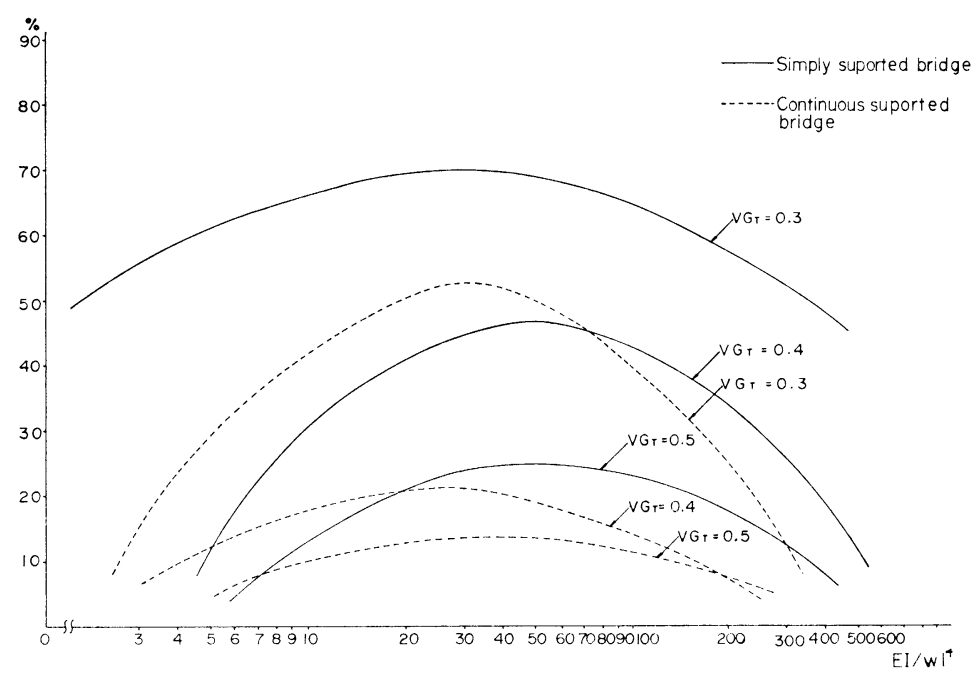

Fig. 15 Probability curve that pedestrians feel such that vibrational greatness is greater than $0.3,0.4$ and 0.5 
連続支持の歩道橋でも，三，三の歩道橋では， $V G_{T}$ が 0.3 を越える確率が極めて大となっている.

\section{6. 振動の心理的大きさの設計への導入}

Fig. 14 はすでに述べたように, $g E I / w l^{4}$ を設計のパ ラメーターと見なしたとき，振動の心理的大きさが 0.3 を越える確率を与えている. 振動の大きさとして 0.4 あ るいは 0.5 を採っても，Fig. 14 に似た曲線が得られ る. 横軸を $E I / w l^{4}$ としても同様な曲線が得られるが, その一例を Fig. 15 に示す. Fig. 15 は実測值より得 られた回帰曲線であり，それらには5.（2）に述べた性 質があることを頭に入れておかなければならない.

歩道橋を設計するにあたり，まず限界とする振動の心 理的大きさ $V G_{T}$ を定め, さらに大きさの振動の発生す る確率を定めると, それらの数值によって, 単純支持あ るいは連続支持に対して, 採らなければならない剛性の 範囲が Fig. 15 によって与えられる. その範囲として は，ある值以下またはある值以上が，設計条件に適合す る範囲であって, 設計条件に適合しない上限值と下限值

を Fig. 15 は示す. しかし，Fig. 15 によって得られ る下限值より小さな值の場合には強度的に不十分となる ことが期待され，結局 Fig. 15 によると，剛性を大と することによって目的を達し得るという常識的な結果と なる。

設計の出発点となる心理的な振動の大きさの採るべき 值については，さらに検討することが望ましく，本論で は数量的にそれらを与えることはできない.

\section{7. あとがき}

従来構造物の設計に, それの利用者の心理的な応答を 数量的に考慮することは, ほとんど行われていない. 本 論は, 歩道橋のような利用者が限られ, 利用目的が明ら かな場合にはそれが可能であることを述べた。

本論の諸数值は, 武蔵工業大学橋梁研究室の当時学生 であった中島清, 島村与志, 坂牧勉, 高杉樹典, 谷岸淳 一, 吉村恭夫, 武内和夫, 寺下徹らの諸君が杂業論文と して測定解析したデータによっている. また, 数值計算 は, 武蔵工業大学および長大橋設計センターの FACOM 270-30 によったが, 長大橋設計センターによって与え られた数值計算に対する便宜には深い謝意を表するもの である・

本研究の一部には昭和 49 年度文部省試験研究費があ てられたことを付記する。

\section{参 考 献}

1）村上永一：土木構造物の設計とは何か，土木学会誌，57
巻 7 号, pp. 3 6, 1972.

2）小堀為雄・梶川康男：橋梁振動の人間工学的評価法, 土 木学会論文報告集, No. 230 , pp. 23〜 31, 1974.10. 小堀為雄・梶川康男：道路橋の振動とその振動感覚, 土 木学会論文報告集, No. 222, pp. 15 23, 1974.2.

3）三輸俊輔・米川善晴：正弦振動の評価法, 日本音響学会 誌, Vol. 27, No. 1, pp. 11 20, 1971.

三輸俊輔・米川善晴：複合正弦振動とランダム振動の評 価法, 日本音響学会誌, Vol. 27, No. 1, pp. 21 32, 1971.

4）小堀為雄・梶川康男・城戸隆良：振動感覚を考慮した歩 道橋の設計, 橋梁と基礎, Vol. 8, No. 12, pp. 23〜29, 1974.

小堀為雄・梶川康男・城戸隆良：土木学会中部支部講演 会, I -26, 1975 .

5) Scatazini, P. : Vibration Tests on the Bircherweid Foot-Bridge, I.C.E. Monthly, Vol. II, No. 4, 1971/ 72, pp. 189-192.

6) Ruderman, J. : High Rise Steel Office Buildings in the U.S., Structural Engineer, Vol. 43, No. 1, 1965.

7) Chang, F.K. : Wind and movement in tall Buildings, Civil Engineering-ASCE, Aug., 1967, pp. 70-72.

8）西脇威夫添か：歩道橋の振動感覚と二, 三のパラメータ との関係について，士木学会年次学術講演会，I - 210 , 1973.

振動感覚を考慮する場合の二，三の設計条件について， 日本道路会議, pp. 527, 1973.

Quantitative Analysis of Psychological Response Against Vibration in Bridge Design, Symposium of IABSE, Dresden, Sept., 1975.

9) Chen, P.W. and L.E. Robertson : Human Perception Thresholds of Horizontal Motion, Journal of the Structural Division, ASCE, Vol. 98, No. ST 8, Proc. Paper 9142, Aug., 1972, pp. 1681-1695.

10) Wiss, J.F. and R.A. Parmelee : Human Perception of Transient Vibrations, Journal of the Structural Division, ASCE, Vol. 100, No. ST 4, Proc. Paper 10495, April, 1974, pp. 773-787.

11) Chang, F.K. : Human Response to Motions in Tall Buildings, Journal of the Structural Division, ASCE, Vol. 99, No. ST 6, Proc. Paper 9811, June, 1973, pp. $1259-1272$.

12) Hansen, R.J., J.W. Reed and E.H. Vanmarcke : Human Response to Wind-Induced Motion of Buildings, Journal of the Structural Division, ASCE, Vol. 99, No. ST 7, Proc. Paper 9868, July, 1973, pp. 15891605.

13) Reed, J.W. : Wind Induced Motion and Human Discomfort in Tall Buildings, Department of Civil Engg., Research Report R 71-42, Illinoi Univ., Nov., 1971.

14) Steffens, R.J. : Structural Vibration and Damage, Building Research Establishment Report, Department of the Environment, U.K., 1974, pp. 14-23.

15) Solomon, K.M., Solomon, R.J. and Silien, J.S. : Passenger Psychological Dynamics, Sources of Informations on Urban Transportation, Report Number 3, June, 1968, PB 188886.

16) Feld, L.S. : Superstructure for $1350 \mathrm{ft}$ World Trade Center, Civil Engineering-ASCE, June, 1971, pp. 6670.

17）松本嘉司・佐藤秀一・西岡隆・塩尻弘雄：歩行者の特性 を考虑した歩道橋の動的設計に関する研究，土木学会論 
文報告集, No. 205, pp. 63〜 70, 1972.

18）牛尾正之・南条正洋 : 歩道橋の振動に関する諸問題, 日 立造船技報, Vol. 33-3, 1972.

西村 昭・佐々木茂範・牛尾正之：梅新東歩道橋の振動 実験, 橋梁と基礎, Vol. 5, No. 8, pp. 16 20, 1971.

19）小川慶策・片山恒雄 : 橋梁の振動恕限度について, 土木
学会第 27 回年次学術講演会講演概要集, I - 191, 1972.

20）星谷 勝・中根健一：橋の振動による心理的反忘の理論 解析, 土木学会論文報告集, No. 246, pp. 1 8, 1976.

21）小堀為雄・梶川康男：単一動荷重に対する道路橋の振動 感覚，士木学会論文報告集，No. 248, pp. 11 23, 1976.

(1976.6.3 . 受付) 